\title{
FOOD AND TRANSFORMATION IN
}

ANCIENT MEDITERRANEAN LITERATURE 


\section{WRITINGS FROM THE GRECO-ROMAN WORLD SUPPLEMENT SERIES}

Clare K. Rothschild, General Editor

Number 14

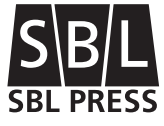




\section{FOOD AND TRANSFORMATION IN ANCIENT MEDITERRANEAN LITERATURE}

Meredith J. C. Warren 


\section{SBRL PRESS}

\section{Atlanta}

Copyright (c) 2019 by Meredith J. C. Warren

All rights reserved. No part of this work may be reproduced or transmitted in any form or by any means, electronic or mechanical, including photocopying and recording, or by means of any information storage or retrieval system, except as may be expressly permitted by the 1976 Copyright Act or in writing from the publisher. Requests for permission should be addressed in writing to the Rights and Permissions Office, SBL Press, 825 Houston Mill Road, Atlanta, GA 30329 USA.

Library of Congress Cataloging-in-Publication Data

Names: Warren, Meredith J. C., author.

Title: Food and transformation in ancient Mediterranean literature / by Meredith J. C. Warren.

Description: Atlanta : SBL Press, 2019. | Series: Writings from the Greco-Roman world Supplement series ; Number 14 | Includes bibliographical references and index. Identifiers: 2019000484 (print) | LCCN 2019009641 (ebook) | ISBN 9780884143574 (ebk.)

| ISBN 9781628372380 (pbk. : alk. paper) | ISBN 9780884143567 (hbl. : alk. paper) Subjects: Food-Religious aspects. | Classical literature-History and criticism Classification: LCC BL65.F65 (ebook) | LCC BL65.F65 W37 2019 (print) | DDC $809 / .93382$-dc23

LC record available at https://lccn.loc.gov/2019000484
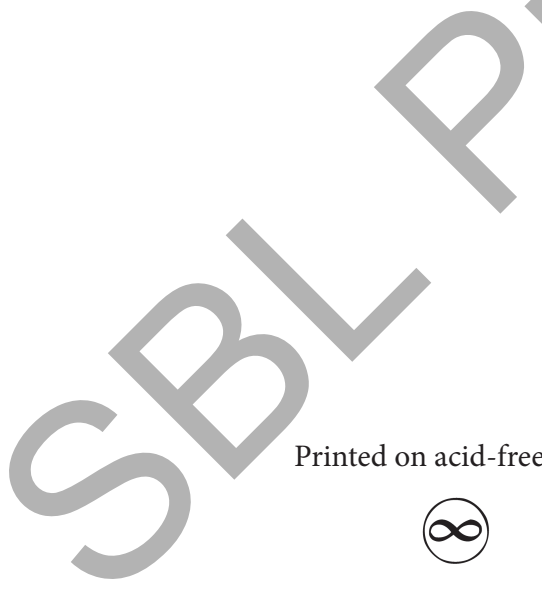

Printed on acid-free paper.

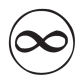


Dedicated to my writing group,

Sara Parks and Shayna Sheinfeld,

without whom this book would not have been written. 


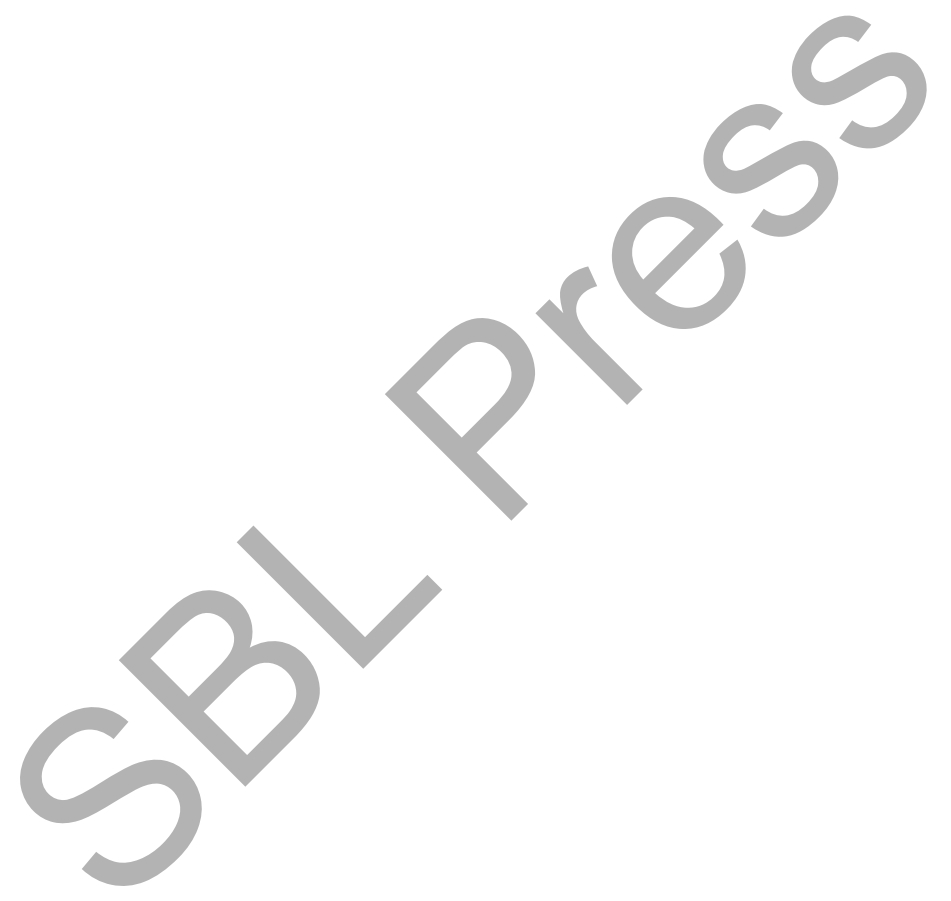




\section{Contents}

Acknowledgments ...............................................................................

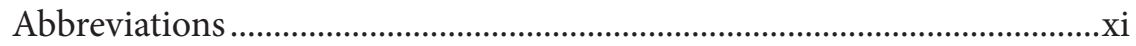

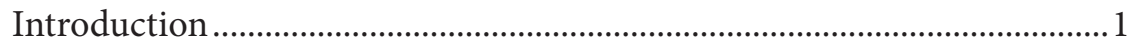

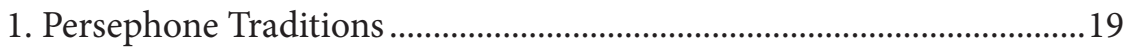

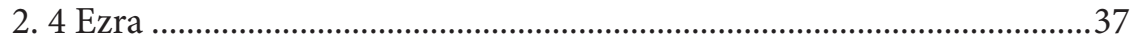

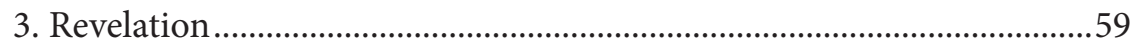

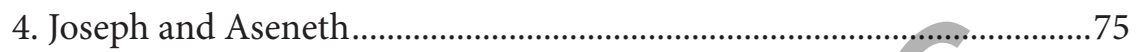

5. Apuleius's Metamorphoses ................................................................101

6. The Passion of Perpetua and Felicitas.................................................129

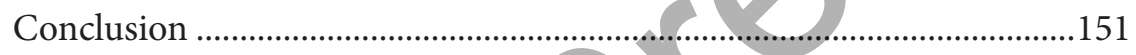

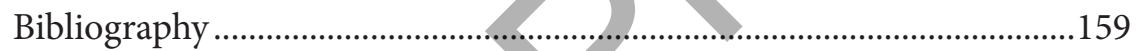

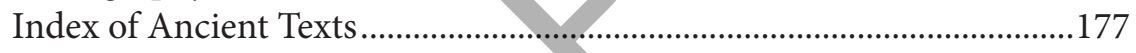

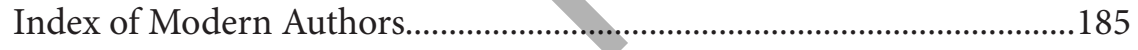

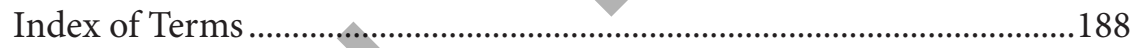




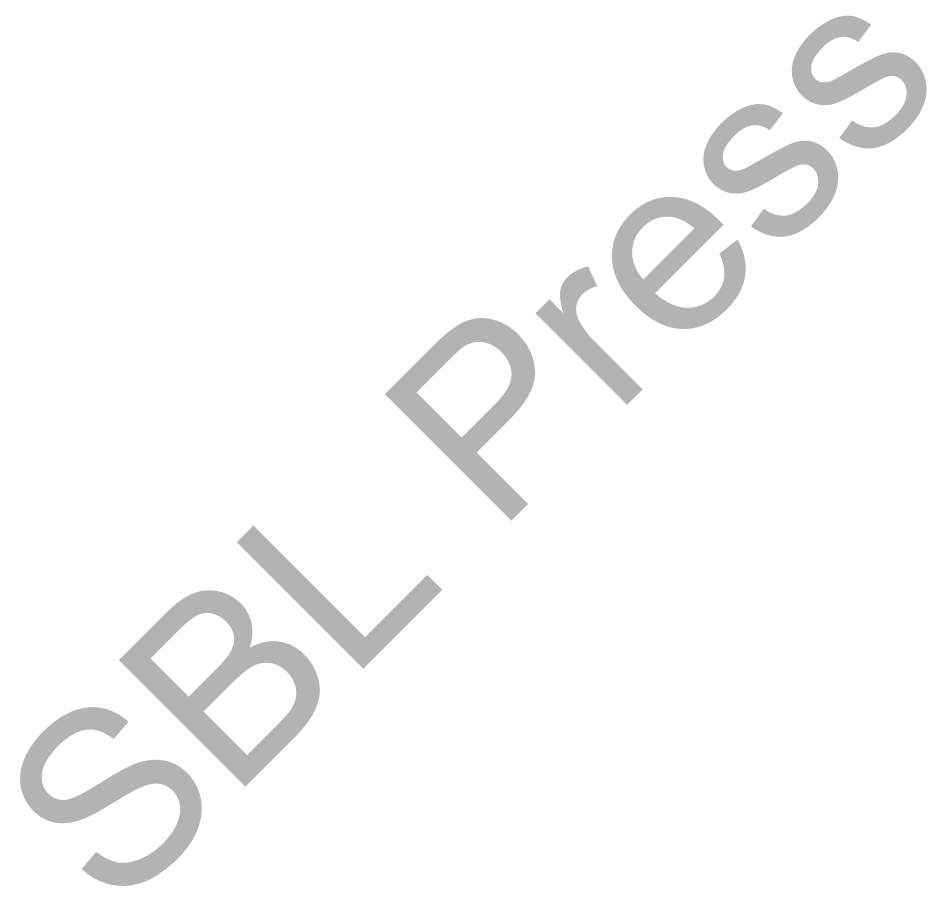




\section{Acknowledgments}

I am indebted to a number of people who were instrumental in helping me wrench this idea out of my head and into a book. First is Ellen Bradshaw Aitken, who first pointed out to me that Aseneth's honeycomb might not be unique. Nicolae Roddy also helped me develop hierophagy as the term to describe this literary genre. Sune Auken talked through aspects of genre theory with me. Shayna Sheinfeld suggested I look at 4 Ezra for an example of hierophagy.

I am grateful to the Fonds de recherche du Québec Post-Doctoral Fellowship of the Government of Québec for awarding me the postdoctoral funding that allowed me to begin this project in earnest and for Adele Reinhartz at the University of Ottawa for helping me develop my research.

I probably could have written something approximating a book by myself, but it would not have been fit to read without the critical editing of my writing group, nor would I have had the encouragement and support I needed to keep working on it, little by little. Thank you, Sara Parks and Shayna Sheinfeld. In that light, I would like to thank my Jessop Left comrades and the friendships forged during 2018 USS strike picket lines, whose camaraderie and sharp workplace analysis helped me learn to carve out time for myself, but also to discover what I value in my job.

My family was and is ever supportive. I thank my patient parents, who gamely kept straight faces every time I told them the book still was not finished and whose constant encouragement made me feel like I could do it. Last but not by any means least, I thank my husband, who cheerfully moved continents for me, put up with my bad writing days and celebrated my good ones, and is an all-around catch. 


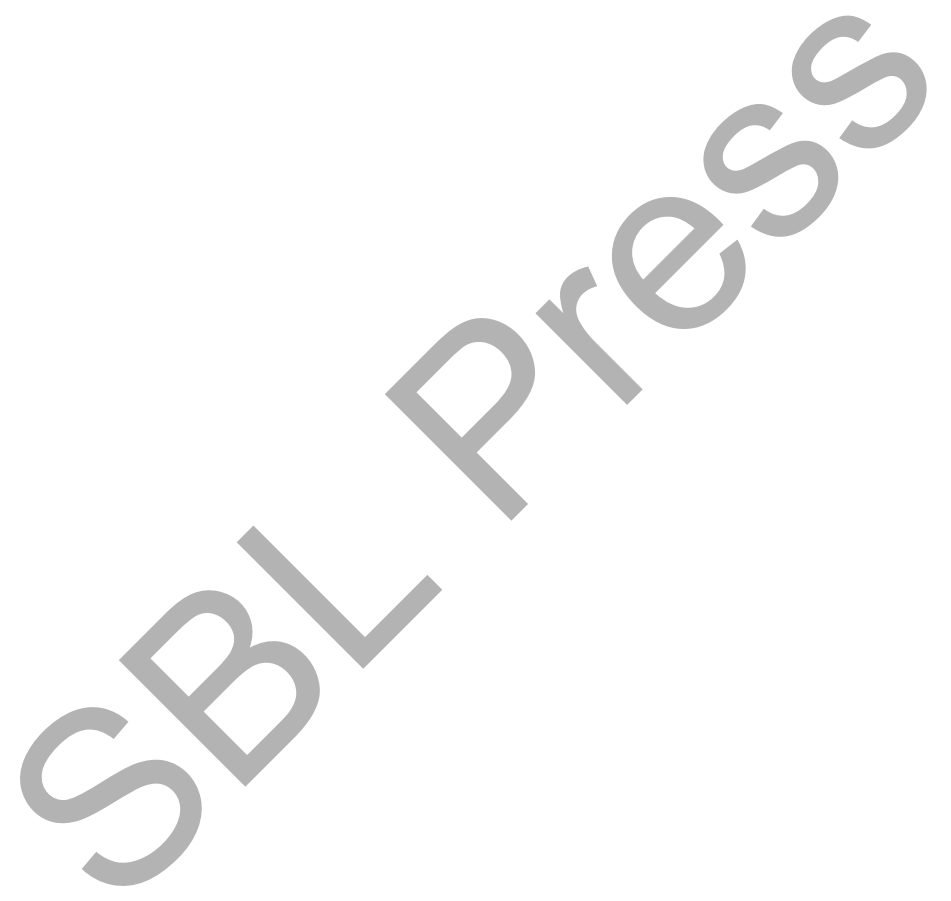




\section{Abbreviations}

Primary Sources

1 En.

1 Enoch

2 En.

2 Enoch

2 Bar.

2 Baruch

3 Bar.

3 Baruch

Achill.

Statius, Achilleid

Agr.

Alex.

Cato, De agricultura; Columella, De re agricultura

Amat. narr.

Nicander, Alexipharmaca

An.

Plutarch, Amatoriae narrations

An. orig.

Antr. nymph.

Apoc. Ab.

Apoc. Adam

Argon.

Aug.

b.

Bib.

Bib. hist.

Tertullian, De Anima

Augustine, De anima et eius origine

Porphyry, De antro nymphorum

Apocalypse of Abraham

Apocalypse of Adam

Apollonius of Rhodes, Argonautica

Suetonius, Divus Augustus

Babylonian Talmud

Apoloodorus, Bibliotheca

Contra haer.

Diodorus Siculus, Bibliotheca historica

Cor. Ephrem the Syrian, Hymnni contra haereses

De an. Tertullian, De corona militis

Descr. Aristotle, De anima

Dion. Pausanias, Description of Greece

Div. haer. Nonnos, Dionysiaca

Ebr. Filastrius of Brescia, Diversarum hereseon liber

Fast. Philo, De ebrietate

Fug. Ovid, Fasti

Galb.

Philo, De fuga et invention

Suetonius, Galba 
Georg.

Haer.

Hag.

Hel.

Hist.

Hist. an.

Hom. Dem.

Il.

Jos. Asen.

Ker.

Leg.

Marc.

Mat. med.

Med.

Metam.

Nat.

Od.

$\mathrm{Ol}$.

Onir.

Or.

Orest.

Pan.

Paneg.

Pass. Perp.

Phars.

Pud.

Sens.

Sifre Num.

Sol.

T. Ab.

Theog.

Ther.

Verr.

Yevam.

Secondary Sources
Vergil, Georgica

Augustine, De haeresibus; Praedestinatus, Praedestinatorum haeresis

Hagigah

Euripides, Helen

Herodotus, Histories

Aristotle, Historia animalium

Homeric Hymn to Demeter

Homer, Iliad

Joseph and Aseneth

Kerithot

Plato, Leges

Tertullian, Adversus Marcionem

Dioscorides, De materia medica

Celsus, De Medicina

Apuleius, Metamorphoses; Ovid, Metamorphoses

Pliny, Naturalis historia

Homer, Odyssey

Pindar, Olympian Odes

Artemidorus, Onirocritica

Aelius Aristides, Orations

Euripides, Orestes

Epiphanius of Salamis, Panarion

Isocrates, Panegyrikos

The Passion of Perpetua and Felicitas

Lucan, Pharsalia

Tertullian, De pudicitia

Aristotle, De sensu et sensibilibus

Sifre Numbers

Plutarch, Life of Solon

Testament of Abraham

Hesiod, Theogony

Nicander, Theriaca

Cicero, In Verrem

Yevamot 
AGJU

AIL

AJEC

ANF

ANRW

ASSR

ATANT

B

BARIS

BETL

BibInt

BZNW

CurBR

DNP

EJL

FCB

FRLANT

HBM

HCS

HSCP

Historia

HTR

HUCA

Int

$J B L$
Arbeiten zur Geschichte des antiken Judentums und des Urchristentums

Ancient Israel and Its Literature

Ancient Judaism and Early Christianity

Roberts, Alexander, and James Donaldson, eds. The Ante-Nicene Fathers: Translations of the Writings of the Fathers Down to A.D. 325. 10 vols. 1885-1887. Repr, Peabody, MA: Hendrickson, 1994.

Temporini, Hildegard, and Wolfgang Haase, eds. Aufstieg und Niedergang der römischen Welt: Geschichte und Kultur Roms im Spiegel der neueren Forschung. Part 2, Principat. Berlin: de Gruyter, 1972-.

Archives de sciences sociales des religions

Abhandlungen zur Theologie des Alten und Neuen Testaments

Burchard, Christoph. Joseph und Aseneth. PVTG 5. Leiden: Brill, 2003.

BAR International Series

Bibliotheca ephemeridum theologicarum lovaniensium

Biblical Interpretation

Beihefte zur Zeitschrift für die neutestamentliche Wissenschaft

Currents in Biblical Research

H. Cancik and H. Schneider, eds. Der Neue Pauly: Enzyklopädie der Antike. Stuttgart: Calwer, 1996-.

Early Judaism and Its Literature

Feminist Companion to the Bible

Forschungen zur Religion und Literatur des Alten und Neuen Testaments

Hebrew Bible Monographs

Hellenistic Culture and Society

Harvard Studies in Classical Philology

Historia: Zeitschrift für Alte Geschichte

Harvard Theological Review

Hebrew Union College Annual

Interpretation: A Journal of Bible and Theology

Journal of Biblical Literature 
JJS

$J R S$

JSJ

JSJSup

JSNT

JSP

JSPSup

LCL

LS

LSJ

LTQ

LXX

NETS

NewDocs

NovT

OCD

OTP

P.Oxy.

$\mathrm{Ph}$

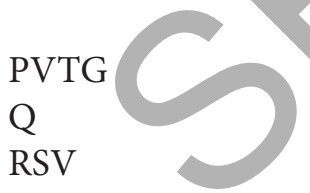

Journal of Jewish Studies

Journal of Roman Studies

Journal for the Study of Judaism

Supplements to the Journal for the Study of Judaism Journal for the Study of the New Testament Journal for the Study of the Pseudepigrapha Journal for the Study of the Pseudepigrapha Supplement Series

Loeb Classical Library

Liddell, Henry George, and Robert Scott. An Intermediate Greek-English Lexicon: Founded upon the Seventh Edition of Liddell and Scott's Greek-English Lexicon. New York: Harper \& Brothers, 1889.

Liddell, Henry George, Robert Scott, and Henry Stuart Jones. A Greek-English Lexicon. 9th ed. with revised supplement. Oxford: Clarendon, 1996.

Lexington Theological Quarterly

Septuagint

Pietersma, Albert, and Benjamin G. Wright. A New English Translation of the Septuagint. Oxford: Oxford University Press, 2014.

Horsley, G. H. R., et al., eds. New Documents Illustrating Early Christianity. North Ryde, NSW: The Ancient History Documentary Research Centre, Macquarie University, 1981-.

Novum Testamentum

Hornblower, Simon, and Antony Spawforth, eds. Oxford Classical Dictionary. 4th ed. Oxford: Oxford University Press, 2012.

Charlesworth, James H., ed. Old Testament Pseudepigrapha. 2 vols. New York: Doubleday, 1983-1985. Grenfell, Bernard P., et al., eds. The Oxyrhynchus Papyri. London: Egypt Exploration Fund, 1898-.

Philonenko, Marc. Joseph et Aséneth: Introduction, texte critique, traduction et notes. SVTP 13. Leiden: Brill, 1968.

Pseudepigrapha Veteris Testamenti Graece

Qur'an

Revised Standard Version 
SBLMS

SBLTT

SC

SEG

$S R$

SymS

WBC

WUNT
Society of Biblical Literature Monograph Series Society of Biblical Literature Texts and Translations Sources chrétiennes

Supplementum epigraphicum graecum

Studies in Religion/Sciences Religieuses

Symposium Series

Word Biblical Commentary

Wissenschaftliche Untersuchungen zum Neuen Testament 


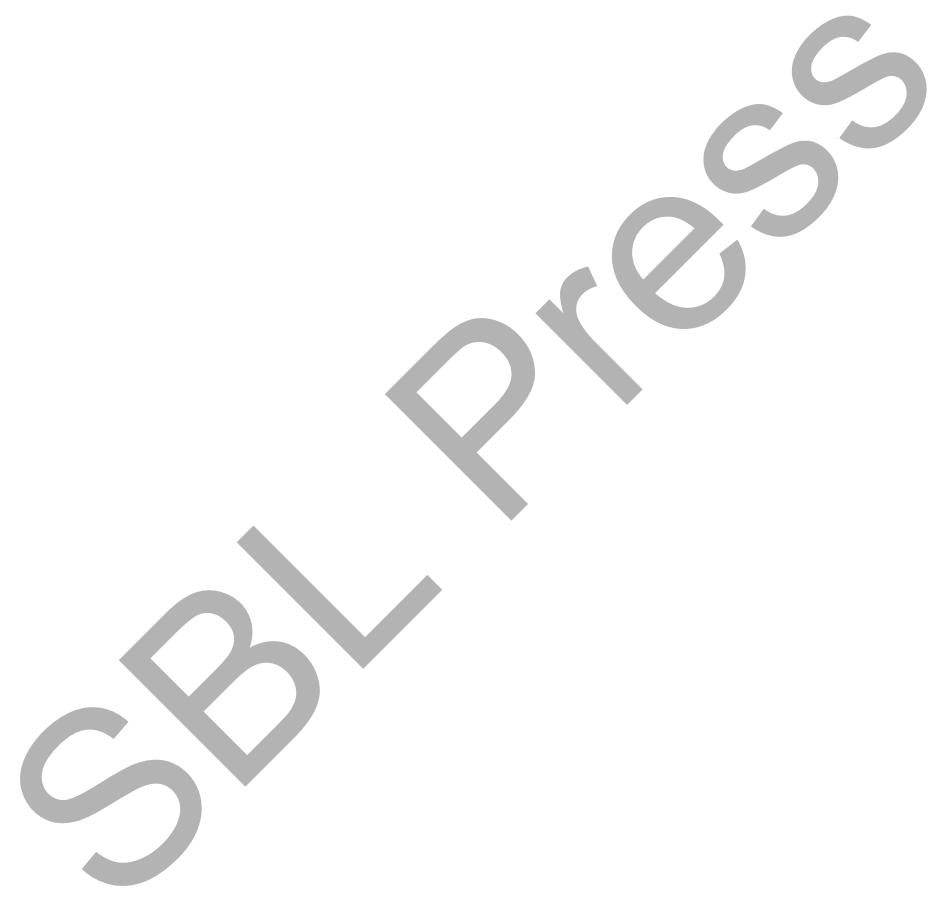




\section{Introduction}

Whether we recognize it or not, taste informs our interactions with the world, filtering information through our cultural lenses and signifying all manner of social meanings. Metaphors of flavors garnish our language: melodies are sweet; memories are bitter; we are left with a bad taste in our mouths; when frustrated, we might use salty language. Eating and tasting, and their constructed meanings, are reflected in the literature we produce and consume. Each morsel is a loaded symbol that is ingested and digested according to expectations we may not even know we have. Ancient literature likewise works through assumed symbolic associations that reflect understandings about food, eating, and taste. Sometimes food and its ingestion are ordinary, or part of a well-known meal practice; sometimes it is very peculiar. In certain cases, eating brings about unexpected results, such as the transformation of the eater or the opening of windows into another realm. Such examples in literature are relatively common, but neither the pattern itself, nor the reason for the pattern, have been investigated.

The purpose of this book is to articulate a category of narrative-level transformative eating. I call this category hierophagy, a term that has been used, infrequently and uncritically, to point to specialized, sacred eating. ${ }^{1}$

1. Apart from my own use of the term (Meredith J. C. Warren, “Tasting the Little Scroll: A Sensory Analysis of Divine Interaction in Revelation 10:8-10," JSNT 40 [2017]: 101-19; Warren, "My Heart Poured Forth Understanding: 4 Ezra's Fiery Cup as Hierophagic Consumption," SR 44 [2015]: 320-33; Warren, “Tastes from Beyond: Persephone's Pomegranate and Otherworldly Consumption in Antiquity," in Taste and the Ancient Senses, ed. Kelli C. Rudolph [London: Routledge, 2017]; Warren, "Like Dew from Heaven: Honeycomb, Religious Identity and Transformation in Joseph and Aseneth" (MA Thesis, McGill, 2006]) and two conference presentations by Nicolae Roddy ("Taste and See...: Hierophagy as Religious Experience" [paper presented at the Trends of Ancient Jewish and Christian Mysticism Seminar (TAJCM), University of Dayton, 7 March 2008]; "Fill Your Stomach with It: Hierophagy as Religious Experi- 
My use of hierophagy here represents a significant development in definition from these brief previous allusions. This category of transformative eating is a recurring pattern of language that expresses both shared and particular meanings across several ancient texts; this pattern also reflects something of the expectations of the societies that found this pattern expressive.

My narrative-level approach to the primary sources is differentiated from a historical or sociological approach in that I will consider the literary ramifications of transformative eating rather than any links this type of eating may or may not have to historical ritual or sacred meals. Examining texts at the narrative level allows the hierophagic event to be understood as part of the literary toolbox used by ancient authors to transmit a certain understanding of the relationship between God and mortals, heaven and earth.

\section{Definition}

My definition of hierophagy emerges from a close reading of the texts examined in the present volume, but also applies to other examples not treated here. In its essence, hierophagy is a mechanism by which characters in narrative cross boundaries from one realm to another. In all cases, and as the term suggests, this is accomplished by the character consuming some otherworldly item. ${ }^{2}$ With specific contexts removed, a generic pattern emerges in which a mortal character interacts with another realm.

ence" [paper presentenced at the Annual Meeting of the Society of Biblical Literature, San Diego, CA, 20 November 2007]), the term is only used in two other places. Roddy suggested I use the term hierophagy to describe the phenomenon I was examining in my research. At the time Roddy understood that he was responsible for the neologism but later found it referred to in Henri Desroche, Jacob and the Angel (Amherst: University of Massachusetts Press, 1973), 40 n.18. Desroche gives credit for the term to F. A. Isambert, review of Religion and Society in Tension, by Charles Y. Glock and Rodney Stark, ASSR 21 (1966): 183-84, but I have not been able to find the term in this citation. I have since also found the term in the work of Oskar Pfister, who simply defines it as a "sacral meal [that] represents the eating of the god or of the holy entity" (Christianity and Fear: A Study in History and in the Psychology and Hygiene of Religion, trans. W. H. Johnston [London: Allen \& Unwin, 1948], 262).

2. While certain patterns emerge in terms of what kinds of things are consumed, the item is not always food-I merely use the word food here and throughout as a general term indicating that something is ingested, whether or not that item is liquid or solid, or even edible in an ordinary context. 
The character ingests something from that realm, and the act of eating precipitates a change in the character such that the character is more closely related to the other realm. The eating of this otherworldly food brings about three specific transformations, both physical and ontological:

(1) Hierophagy binds the person to the place of origin of that food. All of the incidents of ritual eating to be discussed below result in the eater having some close tie to another world. This is most obvious with the Persephone story and Perpetua's vision. Persephone, having eaten the pomegranate, is bound to remain in Hades, while Perpetua's cheese meal points to her impending access to heaven as a martyr.

(2) Hierophagy transforms the eater in some way. While the most extreme case of transformation is Lucius's in Metamorphoses, since he transforms from an animal into a human being, the other recipients of this kind of food are also changed in their own ways. Ezra, Ezekiel, and John of Patmos, for example, have new abilities after their hierophagic meals: the prophets are given the ability to speak to their audience and to prophesy truly. Joseph and Aseneth also participates in this phenomenon of transformation: Aseneth becomes physically transformed, so much so that the members of her family scarcely recognize her (Jos. Asen. 18.9), and is described as chosen (like the visitor, the bees, and Joseph himself) after eating the honeycomb (18.11).

(3) Hierophagy transmits knowledge. Some eaters of otherworldly food receive knowledge directly related to their heavenly situation. Perpetua is a clear example of this phenomenon since she receives the knowledge of her impending martyrdom. Ezekiel and John eat the scroll in order to gain special divine knowledge of what God wants them to prophesy, while Ezra drinks from the cup in order to re-receive the Torah and hidden books, just like Moses received the Torah before him. Lucius, after he is transformed, becomes initiated into the mysteries of Isis. Aseneth's visitor tells her that the mysteries of the Most High had been revealed to her.

This study is founded on a literary analysis of ancient texts, closely reading and exploring, on the one hand, the role of the hierophagic scene within the overall narrative and, on the other hand, the commonalities among the hierophagic scenes across the variety of texts under examination. These commonalities, however, do not suppose a direct influence among the texts that make use of the genre of hierophagy. In other words, except for Ezekiel and Revelation, the inclusion of hierophagy in these narratives is due to shared cultural expectations within the ancient Mediterranean milieu rather than literary dependence of one text upon another. 
These narratives use the consumption of otherworldly food to convey the idea of transformation because of ancient assumptions about how food facilitates the transgression of boundaries.

Approaching texts as representatives of cultural ideas about the relationship between this world and other worlds also means that specific dates for textual production do not play a significant role in my analysis. For the most part, the texts I examine here fall into a range of three hundred years on either side of the zero-mark, although some texts touched upon briefly, such as Ezekiel and the Homeric Hymn to Demeter, are older than this and are analyzed for the purpose of elucidating related narratives that do fall in this range. This is not to say that hierophagy as a narrative phenomenon is contained within this range of dates; on the contrary, much earlier examples (i.e., the story of the fall in Genesis) and much later examples (Alice in Wonderland [1865 (film 1951)], The Matrix [1999], Spirited Away [2001], etc.) exist. Rather, this is the period of time in which a high concentration of texts have made use of hierophagy, and thus my chosen era allows for the most fruitful comparison of such texts.

\section{Genre as Fictional Action ${ }^{3}$}

To understand patterns of discourse across a range of texts and cultures, it is necessary to employ a system of analysis that articulates how these patterns emerge and diverge and that explains their resonance internally and in a broader context. Genre as an analytical method allows for such an explanation. Traditional ideas of genre in literary studies are not altogether distinct from form criticism in biblical studies; in broad strokes, these categories of analysis can be useful for understanding the relationship of texts as a whole to each other. However, the pattern of discourse I identify in this book requires more precise tools. Carolyn R. Miller's 1984 work on genre as social action created a more precise way of understanding genre that moved beyond Aristotelian genre categories and their derivatives. ${ }^{4}$ She proposes a five-part understanding of genre:

3. This heading is taken from Sune Auken, "Genre as Fictional Action: On the Use of Rhetorical Genres in Fiction," Nordisk Tidsskrift for Informationsvidenskab og Kulturformidling 2.3 (2013): 19-28.

4. Carolyn R. Miller, “Genre as Social Action," Quarterly Journal of Speech 70 (1984): 152. 
1. Genre refers to a conventional category of discourse based in large-scale typification of rhetorical action; as action, it acquires meaning from situation and from the social context in which that situation arose.

2. As meaningful action, genre is interpretable by means of rules; genre rules occur at a relatively high level on a hierarchy of rules for symbolic interaction.

3. Genre is distinct from form: form is the more general term used at all levels of the hierarchy. Genre is a form at one particular level that is a fusion of lower-level forms and characteristic substance.

4. Genre serves as the substance of forms at higher levels; as recurrent patterns of language use, genres help constitute the substance of our cultural life.

5. A genre is a rhetorical means for mediating private intentions and social exigence; it motivates by connecting the private with the public, the singular with the recurrent. ${ }^{5}$

Miller's definition allows intercourse between the social realm and the realm of discourse, articulating that genres are culture-bound ways of expressing even the smallest action and ways of creating meaning from those actions. In other words, genres are functional and bring about action in those participating in the discourse.

Miller's theoretical approach to genre resides in the real, social world of human interaction, moving away for the most part from analysis of literature or narrative worlds. Sune Auken has begun to apply Miller's analysis of genre in the social realm to the fictional realm. Auken points out that, because all characters within fiction are creations, rather than real social beings, the only social action that occurs takes place within the narrative realm and has no effect whatsoever on the social relationships of the real world. ${ }^{6}$ However, internal to the narrative these generic actions advance the action of the story. Within the fictional frameworks social action takes place and creates meaning that characters react to and understand. The creation of this meaning, just as in the real, social world, is understandable within that created world and its systems. ${ }^{7}$ Auken discusses human social ends that characters attempt to achieve according to certain genres; however, the social must include not

5. Miller, "Genre as Social Action," 163.

6. Auken, "Genre as Fictional Action," 20.

7. Auken, "Genre as Fictional Action," 22. 
just human interactions but also interactions with the divine realm, which likewise take place according to structures of meaning.

I agree with Auken that the analysis of genre as social action can apply to the fictional realm. Indeed, it is this kind of analysis that allows hierophagy to be visible. In other words, as a genre, hierophagy is a symbolic way of expressing meaning within a culture that holds certain expectations around category hierarchy and order, such as the division of heaven and earth, the implications of taste and eating, and the accessibility of the former by way of the latter.

A genre analysis of hierophagy allows me to remain in the world of narrative and discourse, even as I analyze the social, cosmological, and ontological relationships affected by the hierophagic act. Even if these meals were to reflect eating rituals practiced in a historical community - and I make no claim either way-the representation of eating otherworldly food in narrative serves a distinct function within the text. ${ }^{8}$ In other words, this study treats the narrative world as worthy of study in its own right, with its own conventions and producing its own realities. As such, hierophagy participates in what might be called a "ritual in ink" - a phrase used by Jorg Rüpke to highlight the importance of the narrative world, especially in its depiction of performance:

If rituals matter in society, literary rituals must matter in texts. Rituals in ink matter. Ancient texts do not constitute a hermetically sealed realm.

8. I must emphasize that hierophagy is not the pharmacological altering of an individual's state through a drug. Part of the reason why this is not the case is that the items consumed in hierophagy are frequently not considered edible, or they would be considered edible but for some small modification (e.g., a cup full of liquid is ordinarily consumable, but a cup full of flames is not). A pharmacological approach to religious eating-as has been attempted, unsuccessfully in my opinion, by John M. Allegro, Carl A. P. Ruck, Blaise D. Staples, and Clark Heinrich, among others-obscures the narrative-level activity that this type of meal brings about. Indeed, given that we know little about the actual activities of ancient mystics around the Mediterranean, we cannot responsibly say anything about whether consumptive practices described in narratives reflect actual practices. My current focus on the use of hierophagic behaviours in the narrative realm respects indigenous categories of thinking as preserved in ancient texts. For examples of what I am not doing, see, e.g., John Marco Allegro, The Sacred Mushroom and the Cross: A Study of the Nature and Origins of Christianity within the Fertility Cults of the Ancient Near East (Garden City, NY: Doubleday, 1970); Carl A. P. Ruck, Blaise D. Staples, and Clark Heinrich, The Apples of Apollo: Pagan and Christian Mysteries of the Eucharist (Durham, NC: Carolina Academic Press, 2001). 
Texts participate in the wider society in which they were created. In that space texts have a performative dimension regardless of the mimetic or fictitious character of their embedded rituals. ${ }^{9}$

Or, as Auken writes,

regardless of whether imitation is to make an action mirror real life or simply to make it look real, the genres brought into the story will, one way or the other, be recognizable from the culture surrounding the work, and knowledge of the genres of a given culture may be a prerequisite for understanding its narratives. ${ }^{10}$

The importance of narrative-level performance to the narrative events has been underappreciated; this study participates in the move to prioritize an examination of this kind of event, especially as it reflects not an equivalent historical ritual, but rather a pervasive worldview that has crafted the genre governing the accessibility of other realms.

Indeed, rather than revealing a one-to-one reflection of historical meal rites in antiquity, the examples of hierophagy investigated here reflect a cultural understanding of how otherworldly food works to transform. This understanding is part of a "genre of social action," 11 preserved in fiction. Our understanding of patterns of engagement with our surroundings, which is to say our ability to anticipate generic elements in our everyday lives, ${ }^{12}$ is the same mechanism by which we communicate and interpret meaning in literature. It is also the reason we recognize "utterances"13 that play with genre: "the anticipation, however, need not necessarily be fulfilled. It can instead be the subject of counter-play, modification, or parody, thus activating the viewers' pre-existing knowledge in the course

9. Jörg Rüpke, Introduction to Rituals in Ink: A Conference on Religion and Literary Production in Ancient Rome Held at Stanford University in February 2002, ed. Alessandro Barchiesi, Jörg Rüpke, and Susan A. Stephens, Postdamer altertumswissenschaftliche beiträge 10 (Stuttgart: Steiner, 2004), vii-viii.

10. Auken, "Genre as Fictional Action," 22.

11. Miller, "Genre as Social Action," 151-67.

12. Auken, "Genre and Interpretation," 163.

13. Utterances in the context of hierophagy refer to the food given to the eater: the honeycomb, the roses, the cheese, the scroll, the pomegranate, and the cup. Each of these utterances participates in the genre, contributing to its overall form, while also diverging from it in ways that are meaningful to the individual narrative. 
of meaning-making of this specific utterance." ${ }^{14}$ This preexisting knowledge is crucial for hierophagy: it is this knowledge, shared among the ancient communities that produced texts, that allows authors and readers to create meaning out of the hierophagic experience. That is, the presence in literature of so many examples of this kind of transformational eating suggests that this literary genre represents real-world expectations of the ramifications of consuming heavenly food, with or without a hypothetical practice behind it. "Genre manifests existing cultural norms." 15 Genres cannot exist without shared cultural knowledge. The present book leaves aside any investigation of historical ritual(s) behind these examples, since (1) the purpose of this work is to trace the genre and its function and (2) such reconstructions from narrative are notoriously difficult, as previous studies of many of the texts examined here have proven. ${ }^{16}$

Two important features of many of the narratives examined in the present volume warrant particular attention. First, many biblical examples of hierophagy are preserved in apocalyptic or protoapocalyptic texts; many of those Jewish or Christian noncanonical texts that could not be properly termed apocalypses also embed their hierophagic events in apocalyptic scenes. The non-Jewish and non-Christian examples of hierophagy, on the other hand, do not participate in the apocalyptic genre, even though the Hellenistic world "provided the matrix for apocalyptic literature." 17 Thus, while Christian and Jewish examples of hierophagy use apocalyptic imagery to convey the transformation that occurs as a result of eating otherworldly food, non-Jewish/non-Christian examples do not. Perhaps this is because Jews and Christians used apocalypses to talk about the heavenly realm-after all, one of the features by which apocalypses are defined is a dualistic "spatial axis" of the earthly and the heavenly realms. ${ }^{18}$

Second, and perhaps relatedly, many of the examples examined in this study depict the hierophagic event as part of a vision or a dream. The

14. Auken, "Genre and Interpretation," 163.

15. Sune Auken, "Genre and Interpretation," in Genre and ... , ed. Sune Auken, Palle Schantz Lauridsen, and Anders Juhl Rasmussen, Copenhagen Studies in Genre 2 (Copenhagen: Ekbatana, 2015), 155 n. 1.

16. For a discussion of previous interpretations of the texts relevant to this study, see the dedicated chapter for each text.

17. John J. Collins, The Apocalyptic Imagination: An Introduction to Jewish Apocalyptic Literature (Grand Rapids: Eerdmans, 1998), 37.

18. John J. Collins, "Introduction: Towards the Morphology of a Genre," Semeia 14 (1979): 7. 
fact that the events under discussion here frequently take place in dreams does not take away from their narrative reality. As Frances FlanneryDailey points out, "whereas we tend to view dreams as unreal, interior, subjective phenomena, ancient peoples believed that some dreams were genuine visits from deities or their divine representatives." 19 Thus, the distinction that we moderns maintain between "dream" and "vision," where one is imaginary and the other true, is not enforceable in ancient modes of thought. Whether while sleeping or while awake, interaction with the divine sphere was taken as a reasonable, if infrequent, occurrence-one which is represented also in literature which deals with how human beings envision their relationship to the other realms.

\section{Other Worlds, Other Foods}

In reviewing the history of scholarship on otherworldly journeys and access to divine realms, I articulate the importance of the porous-but-present boundary between worlds in the cultural expectation of the ancient Mediterranean cultures, and as such, the significance that mechanisms for breaching those boundaries held. Many ancient texts demonstrate a preoccupation with regard to the difference between angelic/otherworldly food and mortal/earthly food, even in texts that do not contain hierophagic events. The anxiety displayed by angelic characters in mortal disguise at the prospect of eating human food, for instance, suggests that divine/mortal geographical boundaries are also reflected in the distinction between heavenly and mortal foods, as the texts under examination in this volume also illustrate.

One example of this porous boundary is the Testament of Abraham, a first-century CE text that does not include a hierophagic scene but that nonetheless expresses angelic apprehension at the prospect of consuming earthly food. In the Testament of Abraham, the angel Michael visits Abraham to give him the news of his impending death. While there, Abraham observes culturally expected hospitality rites and presents the angel with a table of food for the two to share. Michael returns to heaven to ask God for advice, since, as an angel, he cannot eat human food. ${ }^{20}$ Michael argues, "Lord, all the heavenly spirits are incorporeal, and they neither drink

19. Frances Flannery-Dailey, Dreamers, Scribes, and Priests: Jewish Dreams in the Hellenistic and Roman Eras, JSJSup 90 (Leiden: Brill, 2004), 1.

20. See also, David Goodman, “Do Angels Eat?”, JJS 37 (1986): 160-75. 
nor eat, and he has set a table with an abundance of good things that are earthly and corruptible" (T. Ab. 4 [Recension A]). ${ }^{21}$ Michael is incapable or unwilling to eat the same food as Abraham-it is corruptible, just as Abraham is susceptible to the death Michael is about to pronounce upon him. ${ }^{22}$ This division between heavenly and mortal creatures seems to be articulated in what each category of being consumes. ${ }^{23}$

This culturally understood division between human and divine food can also be observed in certain accounts of how human beings prepare for contact with the divine. So, for instance, Moses does not eat during his encounter with God on the mountain (Exod 34:28); Daniel does not eat food or drink wine for three weeks prior to his vision (Dan 10:2-3); Ezra fasts prior to his second and third revelatory episodes (4 Ezra 5.20; 6.35); and Baruch fasts before his encounters with the divine (2 Bar. 5.7; 9.1; 12.5; $20.5-21.1 ; 43.3 ; 47.1 ; 86.1)$. In fasting, humans separate themselves from ordinary life, creating space for the divine realm to punctuate the earthly realm. ${ }^{24}$ Hierophagy, however, involves eating the food of another realm,

21. E. P. Sanders, trans. “Testaments of Abraham," OTP 1:871-902.

22. The issue is resolved by God, who sends with Michael a "devouring spirit," invisible to Abraham, which will consume all the food that Michael brings to his mouth while making it appear that Michael himself is sharing in Abraham's table.

23. Of note in this discussion are two passages in the Qur'an which discuss the difficulties in sharing table fellowship with angels. Quran Hud 11:69-70 discusses the visit of the angels to Abraham at Mamre (cf. Gen 18:1-8, where the three visitors Abraham receives do eat): "Our messengers came to Abraham with good news. They said: 'Peace!'; he said: 'Peace!', and immediately set about bringing in a roast calf. When he saw their hands did not reach out towards it, he felt uneasy with them and started to be afraid of them. They said: 'Do not act afraid; we have been sent to Lot's folk'" (trans. Irving, Ahmad, and Ahsan). Here Abraham serves the messengers according to ordinary hospitality customs, but the angelic visitors do not eat, which makes Abraham uneasy. There is no explanation given as to why these divine messengers do not eat; rather, it is expected within the text that the assumed readers would understand the reason behind this break with hospitality customs. In Q Adh-Dhariyat 51:24-37, we read a similar version of the same account: "Has the report of Abraham's honored guests ever come to you, when they entered his home and said: 'Peace [be upon you]!? He said: '[On you be] peace!' [even though] they were people he did not know. So he slipped off to his family and fetched a fattened calf, and brought it up to them. He said: 'Will you not eat?' He felt a fear concerning them. They said: 'Don't be afraid,' and gave him the news of a clever lad" (trans. Irving, Ahmad, and Ahsan).

24. Carla Sulzbach, "When Going on a Heavenly Journey, Travel Light and Dress Appropriately," JSP 19 (2010): 163-93, esp. 183-84. See also Thomas B. Dozeman, God on the Mountain, SBLMS 37 (Atlanta: Scholars Press, 1989), 34. 
which only those beings residing there are able to consume. Otherworldly food yields different results than the simple absence of human food can bring about.

Just as humans might avoid earthly food in order to gain proximity to the divine realm, so too might divine beings avoid mortal food, lest they compromise their divinity. Many ancient texts indicate that heavenly food is eaten by the gods instead of earthly food. That is, the prohibition on angels eating earthly food is matched by a tendency of gods to eat only heavenly food. In the Septuagint, the Wisdom of Solomon describes

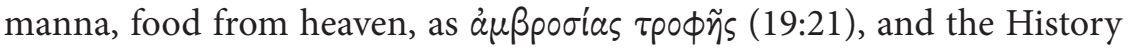
of the Rechabites recounts how the inhabitants of the Isles of the Blessed consume water that comes from the ground tasting like honey, that is, nectar $(7.2 ; 11.4 ; 12.5)$. In the Protoevangelium of James, Mary is fed heavenly food by an angel (8.2), which Lily C. Vuong briefly notes points to Mary's special status. ${ }^{25}$ Vuong likewise draws connections to certain narratives in early Judaism and Christianity where manna as divine food plays a role, but she neglects to include almost all of the texts that depict hierophagy. Nonetheless, this example, as with the others, signals how prevalent the same cultural expectations around heavenly food are that undergird hierophagy.

Comparisons between this biblical heavenly food and the ambrosia of the Homeric gods are therefore warranted. ${ }^{26}$ Ambrosia and nectar are the food of the gods in Greek traditions. ${ }^{27}$ This divine food is reserved for the gods and seems to be the source of immortality. ${ }^{28}$ This food is ordinarily

25. Lily C. Vuong, Gender and Purity in the Protevangelium of James (Tübingen: Mohr Siebeck, 2013), 102-3.

26. Tobias Nicklas, "Food of Angels (Wis 16:20)," in Studies in the Book of Wisdom, ed. Géza G. Xeravits and József Zsengellér, JSJSup 142 (Leiden: Brill, 2010), 95; cf. Fritz Graf, "Ambrosia," DNP 1:581-82; K. Wernicke, "Ambrosia," in Paulys Real-Encyclopädie der Classischen Altertums-wissenschaft (Stuttgart: Calwer 1894): 1:1809-11.

27. See Emily Gowers on ambrosia as a metaphor for sweet kisses, and Sarah Hitch on wine so tasty that it is compared to this divine food. Emily Gowers, "Tasting the Roman World," in Rudolph, Taste and the Ancient Senses, 90-103; Sarah Hitch, "Tastes of Greek Poetry: From Homer to Aristophanes", in Rudolph, Taste and the Ancient Senses, 22-44. Hitch also addresses the dining event between Calypso and Odysseus in Od. 5.194-199. There, Hitch observes, the divine and mortal share space, allowing human proximity to the divine, but not food, marking their distinct natures.

28. Ambrosia literally means immortality. On the gods' consumption of ambrosia and nectar as opposed to mortal food, see Il. 5.342; in Od. 5.135, Calypso indicates 
kept away from mortal people; for instance, when the goddess Calypso dines with Odysseus, we read that "the goddess gave him human food and drink. She sat and faced godlike Odysseus while slave girls brought her nectar and ambrosia" (Homer, Od. 5.197-199 [Wilson]). When human beings do interact with ambrosia or nectar, they do not eat it, ${ }^{29}$ but rather it is poured on or into their bodies in order to prevent, for example, the corruption of a corpse (e.g., Patroclus [Il. 19.37-39], Sarpedon [Il. 16.670, 680]) or the experience of hunger (e.g., Achilles [Il. 19.352-354]). ${ }^{30} \mathrm{It}$ seems that ambrosia must be consumed through the mouth to have its full effect. ${ }^{31}$ Above all, ambrosia as divine food is always contrasted with mortal food. ${ }^{32}$

It is notable that otherworldly food in the texts under examination here is frequently described as sweet. Perpetua awakes from her vision with a sweet taste in her mouth; the scrolls in Ezekiel and Revelation are described as sweet; and Aseneth eats honey itself. ${ }^{33}$ The food of the gods in the Greek tradition is also associated with honey. In the Homeric Hymn to Hermes this is made explicit (559-562), and Porphyry, writing much later, also associates the food of the gods with honey (Antr. nymph. 15-19). ${ }^{34}$ This sweetness finds echoes in the various traditions examined here-in

that she would have made Odysseus immortal (had he eaten ambrosia?) but for Zeus's command through Hermes.

29. Tantalus, a son of Zeus (and therefore half divine), was invited to share the gods' table and their immortal food, but squandered his opportunity when he stole ambrosia to bring back to his drinking companions (Euripides, Orest. 10; Pindar, Ol. 1.95).

30. See also Mark Bradley, "Introduction: Smell and the Ancient Senses," in Smell and the Ancient Senses, ed. Mark Bradley (London: Routledge, 2015), 4.

31. Apollonius, Argon. 4.869-872 implies that had Thetis been successful in completely anointing Achilles with ambrosia, he would have become immortal and ageless, which contradicts this idea. Later tradition (e.g., Statius, Achill. 1.122-223; 269$270 ; 480-481)$ replaces ambrosia as the mechanism of Achilles's potential immortality with the river Styx.

32. Ashley Clements, "Divine Scents and Presence," in Bradley, Smell and the Ancient Senses, 50.

33. The pomegranate that Persephone ingests and the roses eaten by Lucius are not explicitly depicted as sweet in the text, but are also not described as bitter.

34. Susan Scheinberg, "The Bee Maidens of the Homeric Hymn to Hermes," HSCP 83 (1979): 5; see also W. H. Roshcer, Nektar und Ambrosia (Leipzig: Teubner, 1883), 25 et passim. See also Ross Shepard Kraemer, When Aseneth Met Joseph: A Late Antique Tale of the Biblical Patriarch and His Egyptian Wife, Reconsidered (New York: Oxford 
almost every case, the eater is left with the impression of having consumed something sweet, tasting like honey, even when the consumable would not naturally have that flavor, for example, a scroll. This sweet taste operates as a symbol by which the eater interprets his or her experience. Sweetness is representative ${ }^{35}$ and participates in culturally governed expectations of meaning. Our interpretation of taste is bounded by intellectual and cultural categories-the perception of a right or wrong eating experience depends on whether the eater perceives the item ingested as belonging to an accepted edible category first and then on whether the experience of eating the item corresponds to one's expectations of that category. Carolyn Korsmeyer gives the example of a "fluffy yellow mound swallowed under the expectation that it is lemon sherbet" 36 when in fact it is butter. The surprise of expecting one taste and experiencing another is a familiar one and one which depends on a reorientation of categories in order to be reinterpreted as enjoyable or appropriate to eat. This kind of recognition through categorization also informs our understanding of hierophagy, since categories of taste are also at work here. Perpetua, for example, awakes from her vision with a sweet taste in her mouth and correctly interprets it; John of Patmos is forced to reinterpret his taste experience with the scroll, whose sweetness turns bitter once ingested. In the texts under examination here, ingestion creates meaning for the consumer.

\section{Other Approaches to Eating}

I have already said that interpreting how hierophagy works as a genre depends on the culturally held expectations. Representational foods and eating abound in ancient literature, and the culturally bound expectations of taste in general and sweetness in particular are part of their interpretation. Culturally held expectations about food and taste are one factor in understanding how hierophagy functions the way it does. Although I will give an overview of previous approaches to specific food items in individual chapters, there is one feature of ancient taste that potentially affects all the texts examined here and therefore undergirds hierophagy as

University Press, 1998), 169-71, which will be discussed in greater detail in the chapter on Aseneth.

35. Carolyn Korsmeyer, Making Sense of Taste: Food and Philosophy (Ithaca, NY: Cornell University Press, 1999), 115-18.

36. Korsmeyer, Making Sense of Taste, 90-91. 
a genre. As I discussed above, ambrosia and nectar are associated with the divine realm in Greek, Roman, and early Jewish contexts; however, there are also several more specific associations with sweetness in biblical and early Jewish texts that point toward God's wisdom. In other words, while one factor of sweetness supports the element of hierophagy that binds the eater to the other realm, another factor highlights the knowledge-giving function of transformational eating of this genre. In their 2017 article, "Edible Media: The Confluence of Food and Learning in the Ancient Mediterranean," Steven Muir and Frederick Tappenden trace the prominent association between food and eating and learning in biblical texts. ${ }^{37}$ From the tree in Gen $2: 16-18$ and $3: 1-7$ to the Psalms $(19: 10 ; 34: 9)$ to the gospels (Matt 4:4) and to Paul (1 Cor 2:6-3:3), metaphors of tasting and eating are consistently used to point to the ingestion of information in ancient texts. As a metaphor, this is distinct from the genre of hierophagy, in which a literary character performs certain actions within a narrative. However, metaphors function to express meaning that is intended to be interpreted by readers; in that way, metaphors reflect the world that created them and its expectations. Food is a vehicle ${ }^{38}$ by which ancient peoples understood acquiring knowledge. As such, while not identical with what happens in a hierophagic experience, food as metaphor for knowledge works to support hierophagy as a genre, since it articulates the societal association between food and eating and knowledge, whether divine or mortal.

\section{Taste as a Sense}

Since taste was considered one of the baser senses by some ancient philosophers, ${ }^{39}$ the question of how it came to represent access to divine realms is key to this project. It is clear that for many philosophers, vision and hearing were at the top of the sensory hierarchy, since they were considered the means of acquiring knowledge, as opposed to touch and taste,

37. Steven Muir and Frederick S. Tappenden, "Edible Media: The Confluence of Food and Learning in the Ancient Mediterranean," LTQ 47 (2017): 123-47.

38. See Ivor A. Richards, The Philosophy of Rhetoric (Oxford: Oxford University Press, 1936), esp. 95-100.

39. Korsmeyer, Making Sense of Taste, 26-29, 35. For an overview of the human senses, including and beyond the five "classical senses," see John M. Henshaw, A Tour of the Senses: How Your Brain Interprets the World (Baltimore, MD: Johns Hopkins University Press, 2012). 
whose close association with the body sullied their usefulness in terms of pure information. Aristotle states that "among the senses, vision is the most important, both in itself and for the necessities of life; on the other hand, for the uses of reason, and accidentally, hearing is the most important" (Sens. 437a9-10), ${ }^{40}$ while touch is the lowest of the senses (De an. 421a25). For Aristotle, taste is the type of touch that mediates nutrition (Sens. 438b21). ${ }^{41}$ That Aristotle is rather dismissive of taste in its relation to digestion of food for sustaining life highlights a tension in antiquity: while taste as a sense is considered less frequently than sight, food and its pleasures is the subject of constant discussion. The ancient philosophers appear to be uncomfortable engaging with taste as philosophically important because of its relation to the body. ${ }^{42}$ It is more closely tied to the body even than touch, since the body is actually penetrated by the sense-object and in the end, absorbs it.

Since with taste the sense-object is actually internalized by the eater, this kind of interaction with the divine realm has more profound ontological repercussions on the eater than, for example, divinely sent dream visions or oral discourse with a being from another realm; in effect, the consuming of otherworldly foods serves to embed the eater in the realm to which the consumed food belongs. This is one of the cultural expectations that hierophagy as a genre exploits in its construction of meaning.

Taste is therefore the most intimate of the traditional senses in the sense that the object of taste is taken into the body, removing it from public accessibility. ${ }^{43}$ Taste's intimacy with relation to the eater may indicate this sense's popularity in apocalyptic texts, where a certain intimacy with the divine facilitates the acquisition of specialized, hidden, privileged knowledge. This is clear especially in 4 Ezra, where an escalating progression of the senses, from hearing, to seeing, to tasting, leads to the final revelatory experience and yields the revelation of the new Torah. Further, the

40. This bias toward vision and hearing continues in modern and even postmodern philosophy, as Korsmeyer illustrates (Making Sense of Taste, 26-37).

41. Korsmeyer, Making Sense of Taste, 20.

42. The significance of the body in relation to hierophagy and taste will be dealt with more fully in the chapter dedicated to the Passion of Perpetua and Felicitas.

43. Korsmeyer, Making Sense of Taste, 35; Andrea Beth Lieber, "Jewish and Christian Heavenly Meal Traditions," in Paradise Now: Essays on Early Jewish and Christian Mysticism, ed. April D. DeConick, SymS 11 (Atlanta: Society of Biblical Literature, 2006), 316 n. 8 
intimacy inherent in taste is what "betokens the community that eating together promises." 44 That sharing a meal is a significant part of community formation in ancient communities is well established. What I propose is that in hierophagic eating, the bond created is between the eater of the food and the otherworldly giver of the food, who in some cases also shares the meal. This type of bonding through eating participates in accepted ways of building relationships in antiquity but offers a different way of belonging for the privileged eater; he or she belongs to the community of the other realm.

\section{Chapter Outline}

This introduction lays the groundwork for approaching texts that employ hierophagy. I have defined the generic category under discussion and provided methodological approaches of taste and genre analysis to facilitate specific discussion of texts throughout the remaining chapters.

Chapter 1, "Persephone Traditions," begins with a preliminary example of hierophagy from classical Greek and first-century Roman myth. It explores two texts from outside the realm of Jewish and Christian literature that both describe the same hierophagic story, which is that of Persephone or Proserpina. The fact that characters in the myth take for granted the effects of the pomegranate supports my argument that hierophagy is a culturally accepted expectation and that otherworldly food consumption effects significant and often irrevocable change upon the eater, since in both Ovid's Metamorphoses and the Homeric Hymn to Demeter, Persephone is required to reside in Hades after having consumed pomegranate seeds in that realm.

Chapter 2, "4 Ezra," examines the development of apocalyptic hierophagy in the form of the fiery cup in 4 Ezra. I propose that Ezra's seven revelatory experiences reach their pinnacle in the seventh, hierophagic experience, since it is only with this final episode that Ezra is able to understand and transmit the divine knowledge shown to him by Uriel and God. My examination of Ezra's experiences highlight the sensory aspect of hierophagy, since at first he only receives revelation through discourse, then through sight, and finally, with the seventh episode, through taste. Ezra also gains new abilities, namely, the ability to

44. Korsmeyer, Making Sense of Taste, 187. 
transmit his heavenly knowledge to the people; but further, Ezra is taken up into heaven at the end of his revelation. His heavenly assumption reflects the translocational aspects of hierophagy, as seen also in Perpetua's and Persephone's experiences.

Chapter 3, "Revelation," analyzes Revelation's hierophagic scene, Rev 10:8-10, where the sweetness of the scroll turns to bitterness. The mechanism of transformation is not elaborated upon. This is in contrast to the Persephone traditions' legalistic explanation, suggesting that the consequences of otherworldly consumption were part of the accepted understanding of the relationship of this world to the other, heavenly realm, whereby the eater not only gains access to the other world, but also receives heavenly knowledge. John is directed by a voice from heaven to consume the scroll, which tastes sweet; it is only when the scroll is in John's stomach that it turns bitter, signaling both judgement and authority.

Chapter 4, "Joseph and Aseneth," explores the curious honeycomb scene in Jos. Asen. 16-18. I argue that neither initiatory meals nor eucharistic practices are useful comparators in this case; rather, Aseneth's transformation is best understood as hierophagy. When Aseneth is fed the heavenly honeycomb by her angelic visitor, she attains eternal life (16.14), she understands divine wisdom (17.1-2), and she is physically transformed such that she is unrecognizable (18.8-10). While this scene has typically been understood as a conversion, certain elements, such as the fact that Aseneth retains her name and status as an Egyptian, speak against such a conclusion; rather, her affiliation to the divine is characterized in terms that participate in the genre of hierophagic transformation.

In chapter 5, "Apuleius's Metamorphoses," we find another instance of hierophagic eating-one that emphasizes the significance of consuming food from a different ontological category. While the texts examined so far portray the two categories as heavenly and mortal, in the Metamorphoses the categories are human and animal. Lucius, the main character, experiences a transformation through hierophagy that alters his physical appearance: having been transformed into an ass by a curse, Lucius's floral meal returns him to his human form. Lucius's transformation is facilitated by direct instructions from his patron deity, Isis (11.5-6). Lucius follows through on these instructions, eating the roses given to him by a priest of Isis; the priest is someone who is also of a different, more elevated, species compared with Lucius the donkey. The potential for physical transformation through hierophagy is emphasized in this text. 
Chapter 6, "The Passion of Perpetua and Felicitas," examines Perpetua's heavenly vision in Pass. Perp. 4.8-10, which describes how Perpetua enters heaven and is fed a mouthful of cheese. Perpetua's vision gives her knowledge about her impending martyrdom through a very special mechanism, which is the hierophagic meal facilitated by the heavenly shepherd. Previous discussions of this event have assumed it to be some form of eucharistic or baptismal meal, but I propose that it participates in the genre of hierophagy, since Perpetua has already been baptized earlier in the narrative. As in Joseph and Aseneth and Revelation, Perpetua's hierophagic experience involves sweet-tasting food; Perpetua returns from her vision with that sweet taste in her mouth. The knowledge that she will be presently martyred comes from the ritual knowledge that eating food belonging to a world of a different category binds the eater to that other world, a ramification we also saw in Persephone's pomegranate meal. It seems clear that both Perpetua and her "brother" in 4.10 are familiar with the implications of eating otherworldly food and understand the consequences. The food presented to and eaten by Perpetua narratively transforms her from an earthly being to one of the heavenly people. Perpetua's meal exemplifies the translocational aspects of hierophagic meals, in that Perpetua symbolically becomes a member of the heavenly realm in advance of her actual death.

The conclusion examines the ramifications of the identification of this genre, common across religious boundaries and in a variety of geographical locations. Rather than pointing to direct literary influence, except in a few cases, the prevalence of hierophagy in the literature of the ancient Mediterranean suggests a cultural and literary proximity among the various religious communities that inhabited that world. I return to the question of genre analysis and propose that hierophagy as a genre might find use in other fields beyond the study of antiquity. In a broader sense, then, this study of hierophagy promotes increased study of the literary interactions, which in turn may reflect the lived realities of ancient people.

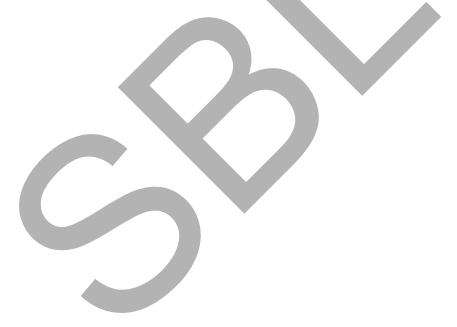

